penditure for the universities from State funds amounts in round figures to $1,800,000 l$. In $19 I_{3}$ the expenditure of the University of Berlin alone was 242,00ol., and of this amount $200,000 l$., or about 83 per cent., was derived from State funds.

The estimates for the year ending March 31, Igr6, show the following grants for universities and colleges in the United Kingdom:-

\section{Great Britain.}

University of London

$\cdots \quad \cdots, 3,000$

Manchester 2,000

University of Wales ... $\quad \ldots \quad \ldots \quad 4,000$

versity of Liverpool $\quad \ldots \quad$... 2,000

Leeds University $\quad \ldots \quad \ldots \quad \ldots \quad \ldots \quad 2,000$

Sheffield University $\ldots . \quad \ldots \quad \ldots \quad$ 2,000

Bristol University $\ldots . \quad \ldots \quad \ldots \quad$ 2,000

$\begin{array}{lllll}\text { Durham University } & \ldots & \ldots & \ldots & 2,00 c\end{array}$

Scottish Universities ... $\quad \ldots \quad \ldots \quad$... 84,000

Colleges, Great Britain $\quad \ldots . \quad \ldots .150,000$

University Colleges, Wales _.. 12,000

Welsh University and Colleges:

$$
\text { Additional Grant } \quad \ldots \quad \ldots \quad \text { 15,000 }
$$

$$
\text { Total } \ldots \quad \ldots \quad \ldots \quad \ldots 287,000
$$

A.-Grants for the General Purposes of the

Queen's University of Belfast

University College, Dublin ...

University College, Cork ...

University College, Galway ...

B.-Grants in respect of the Cost of Purchasing Lands and Providing or Improving the Necessary Buildings and Equipment for the-

National University of Ireland and University College, Dublin ... ... University College, Galway (I85ol. revote) ... ...

C.-Additional Grant in augmentation of sums amounting to I $500 l$ or more contributed from loca sources in $1914^{-1} 5$ towards increasing the Resources of University College, Galway

\section{Total}

Imperial College of ${ }^{\text {Total }} \cdots$ Science and $^{\circ}$ Technology $\quad \ldots \quad \ldots \quad \ldots . \quad \ldots$ Royal College of Science, Dublin ... Technological Work

$$
\text { Grand total } \quad \ldots \quad \ldots \quad f_{5^{17}, 000}
$$

Certain of the universities, colleges, and other similar institutions which are in receipt of Parliamentary grants have been adversely affected by the war, more especially by the loss of fee income arising from the widespread response among men students to the call for recruits. The estimates for $1915-16$ include, therefore, a special grant of $145,000 l$. in aid of such universities, colleges, medical schools, and agricultural institutions, to meet loss of income arising during the war.

\section{Benefactions.}

The benefactions to higher education in the United States during the forty years from 1873 to 1913 amounted to nearly $100,000,000 l$, and are still increasing at the rate of about $5,000,000 l$. annually.

The report of the United States Bureau of Educa- tion for the year ending June 30,1913 , shows that during the year the total sum received in gifts and bequests by universities and other institutions of higher education, excluding grants by the United States, different States, and municipalities, was $4,930,390 l$. Of this amount $895,320 l$. was for increase of plant, $825,980 l$. for current expenses, and 3,209, rool. for endowment. Forty-five institutions reported gifts of more than $20,000 l$.

The income of the $59 \epsilon$ institutions of higher education from which the Bureau receives reports was during the year, from State and municipal grants, $3,809,960 l$.; from invested funds, $3,313,960 l$.; and from fees for tuition and other educational services, $4,183,830 l$.

The Carnegie Institution of Washington has an endowment fund of $4,400,000 l$., and makes grants of nearly $200,000 l$. annually for purely scientific investigations and publications.

The Parliamentary grants in aid of scientific investigation, including the services of the Meteorological Office and the National Physical Laboratory, amount to about $100,000 l$. annually, or $125,000 l$. including the new grant recently made.

The grants for the purposes of medical research, under the National Health Insurance Act, amount to about $56,000 l$. annually.

The total amount appropriated by Parliament to the Development Fund is 2,900,00ol. ; and it is estimated that up to the end of March, I9I6, the expenditure will be on agriculture and rural industries $\mathrm{I}, \mathrm{I00}, 000 \mathrm{l}$., on forestry and afforestation $350,000 l$., and on fisheries I5o,oool.

The Parliamentary grants for universities and colleges in the United Kingdom amount to about half a million annually; the State grants to universities in Germany reach nearly two millions annually.

The benefactions to institutions of higher education in the United States amount to about five millions annually; in the United Kingdom the average is less than one-tenth this sum.

\section{UNIVERSITY AND EDUCATIONAL INTELLIGENCE.}

LONDON.-The following science appointments have been made by the council of Bedford College for Women :- Assistant-lecturer in philosophy, W. A. Pickard-Cambridge; assistant-lecturer in physics, Miss M. O. Saltmarsh; demonstrator in physics, Miss M. Baxter; demonstrators in physiology, Miss Hartwell and Miss Tweedy; demonstrator in geology, Miss I. Lowe.

OxFord.-Captain C. F. Balleine, fellow and subrector of Exeter College, who was killed in action on July 2 (a note on whom appeared on p. 543 of our issue for July 15), bequeathed roool. to the rector and scholars of Exeter College, to be employed in' some way for the benefit of that college as the governing body may direct.

The foundation stone of the new Welsh National School of Medicine at Cardiff was laid on Thursday last by Lord Pontypridd.

A LABORATORY for the investigation of occupational diseases is to be established in Pittsburgh, under the supervision of Dr. J. W. Schereschewsky, of Washington.

A pRoposal is on foot to endow the library of the department of mathematics of Brown University in honour of Prof. N. F. Davis, who, after upwards of forty years' service, is shortly to retire.

THE sum of 8500 dollars has been given by Miss E. Cuyler and Mr. T. De Witt Cuyler to the George NO. 2390 , VOL. 957 
Peabody College for Teachers for the equipment of the Jesup psychology laboratory of the institution.

THE sum of I, I45 dollars has been given to the University of California for the carrying out of the survey of the animal and bird life of the Yosemite National Park, by the California Museum of Vertebrate Zoology.

Dr. F. Billings, of Chicago, is announced to deliver the next course of Lane medical lectures at the School of Medicine of Stanford University. He will take as his subject, "Focal Infection," and the course will extend from September 20 to 25 next.

WE notice the following appointments in connection with American colleges :- Prof. H. S. Jackson, of the Oregon Agricultural College, to be head of the botany department of the Purdue University Agricultural Experiment Station, in succession to Dr. J. C. Arthur; Dr. E. W. Sinnott, of the Bussey Institution, to the chair of botany and genetics at the Connecticut Agricultural College.

Troop College of Technology, Pasadena, has recently received from an anonymous donor the sum of 10,000 dollars towards the equipment of a research laboratory in physical chemistry, and the promise of a like amount yearly for the maintenance of the laboratory. Dr. A. A. Noyes is to be in charge of the new department, dividing his time between Troop College and the Massachusetts Institute of Technology.

According to the Bulletin of the John Rylands Library, Manchester, the appeal on behalf of the University of Louvain which was made by the bulletin has met with a very encouraging reception, upwards of 3000 volumes having already been received or promised. We are glad to learn that an international committee is in process of formation, with the view to co-ordinate the many efforts that are being employed in this country, and also on the Continent, to assist in bringing about the restoration of the devastated library.

THE calendar for the year I9I5 of the National University of Ireland is now available. Among the changes in the courses and in the regulations for the year 1916 of which notice is given may be mentioned those in connection with the matriculation examination, travelling studentships, and the courses for higher degrees. For the purposes of matriculation the University is prepared to accept the certificates of a number of examining boards in the British Isles and Australia, and the matriculation certificates of ten specified universities. In addition, any person who has matriculated in any university of the British Dominions and Colonies, other than those already referred to, and has also passed an Intermediate examination in arts or science in that university, will be exempted from the matriculation examination of the National University of London.

Sir A. H. Church, who died on May 3I, left to the Royal Society his reversionary interest in forty-three 2ol. shares in the London County and Westminster Bank (Limited) with the request that when it falls into possession the income may be applied for purposes connected with the preservation or utilisation of the archives of the Royal Society; $500 l$. to the rector and fellows of Lincoln College, Oxford; to the Waynflete professor of mineralogy in the University of Oxford rool. for the purchase of apparatus and mineral specimens, together with the testator's microscope and other optical instruments and mineral specimens, and his chemical apparatus; and rool. to the curators of the Ashmolean Museum. He further requested his wife to make, among others, the following gifts in her lifetime or bequests at her death:-To the trustees of the British Museum for the mineralogical gallery in NO. 2390, VOL. 95] the Natural History Museum, his collection of cut precious stones, or such thereof as the keeper of the minerals may select; to the curators of the Ashmolean Museum, Oxford, his collection of Japanese sword guards, and of sliders or beads, and of Chinese and Japanese bronzes, several Indian glass sprinklers, and a number of other curios and antiques.

THE Berne correspondent of the Morning Post, quoting from the Akademische Rundschau, gives some interesting information respecting the effects of the war upon the German universities, technical schools, and colleges. It is stated that in the summer term of I914 there were, at the twenty-two German universities, eleven technical academies, five commercial schools, three veterinary schools, and six agricultural and mining schools, 79,077 students entered, a number which in the autumn of 1914 had sunk to 64,710 . Of this number the following were under arms :-

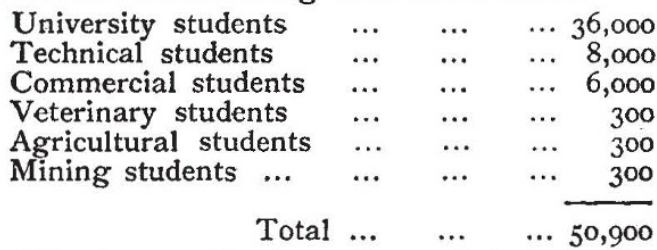

The following are the percentages of students of some of the universities who have gone to the front:Königsberg, 84; Heidelberg, 6o; Munich, 56; Berlin, 54; Frankfurt, II. Of the technical academies Danzig sent the highest proportion of students-90 per cent. The total number of German professors and students killed in the war, up to the end of May, is said to be II9I; Leipzig University has suffered most severely, losing 266 of its students.

\section{SOCIETIES AND ACADEMIES. \\ PARIS.}

Academy of Sciences, August 2.-M. Ed. Perrier in the chair.-G. Bigourdan : The letters of L. Euler in the correspondence of J. N. Deslisle. H. Douvillé : The Orbitoids of Trinity Island. The distribution of these foraminifera is utilised for the classification of the Eocene strata at Trinity Island.-W. Kilian and Antonin Lanquine: The tectonic complications of the south-eastern portion of the, Basses-Alpes, near Castellane.-A. Leduc: The internal pressure of gases. The influence of temperature. Experimental data for sulphur dioxide at temperatures between $0^{\circ}$ and. roo ${ }^{\circ} \mathrm{C}$. are not in good accord with the formulæ of Clausius and Sarrau. A new expression is proposed which presents the experimental results with greater exactness.-Sabra Stefanescu : The origin of some accidents of the crown of elephants' molars.-Louis Gentil : The analogies of the Moroccan Haut Atlas and Atlas of the Sahara.-R. Chudeau : Temperature in western and equatorial Africa.--V. Wallich : The suppression of suppuration in war wounds. The treatment, the very favourable results of which are described, is based on suppressing all causes of irritation at the level of the wound, together with the use of a stringently aseptic dressing. No antiseptics are used, draining tubes are removed as early as possible, and the compresses are moistened with a solution of common salt (one tablespoonful to the litre of water) sterilised by boiling for fifteen minutes before use.-V. Galippe: Parasitism in seeds and its importance in general biology. Experiments carried out on thirty-one species of plants showed that normal seeds can contain parasites. In ninety series of experiments seventy-eight results were positive. The parasite was usually a fungus, more rarely a yeast. The possibility of these parasites causing sudden mutations in plants is discussed.- 